\title{
The Environmental Knowledge and Attitude of Middle-School Students in Five Prominent Green Schools in Indonesia
}

\author{
Widy Anggraini \\ Department of Natural Science \\ Education \\ Universitas Sebelas Maret \\ Surakarta, Indonesia \\ widyanggraini21@gmail.com
}

\author{
Puguh Karyanto \\ Department of Biology Education \\ Universitas Sebelas Maret \\ Surakarta, Indonesia \\ puguhkaryanto@staff.uns.ac.id
}

\author{
Sarwanto \\ Department of Natural Science \\ Education \\ Universitas Sebelas Maret \\ Surakarta, Indonesia \\ sar1to@yahoo.com
}

\begin{abstract}
This research aimed to assess the levels of the environmental knowledge and attitude of the middle-school students in five prominent green schools in Indonesia and to determine the possible factors related to their achievements. The findings were very important in giving feedbacks of the implementation of environmental education in Indonesia, especially in the early educational level. This research relied on the qualitative paradigm. A total of 1203 middle-school students and five Science teachers were involved in the survey and interview. The data related to environmental knowledge and attitude were gathered using a valid and reliable instrument of the environmental-literacy test and a prominent closed-ended questionnaire measuring the levels of ecological paradigm, the New Ecological Paradigm (NEP) Instrument. The data were descriptively displayed using SPSS 17.0. The data related to the Science teachers' perceptions were gathered using in-depth-interview technique. Context analysis was used to draw the observed data to provide the explanation of the factors related to the achievement of the levels of students' knowledge and attitude. The results of the descriptive analysis showed that the participants possessed a low level of knowledge and a middle-ecological level of attitude. The lack of important environmental competencies enhancing environmentally-friendly attitude within the curriculum and poor active and contextual teaching-and-learning processes may be of important factors related to the students' low levels of knowledge and attitudes. Keywords - component, formatting, style, styling, insert.
\end{abstract}

Keywords: Environmental knowledge and attitude, green school

\section{INTRODUCTION}

The root of the cause of the excessive environmental problems nowadays is mainly related to human behaviors $[1,2]$. According to the Theory of Planned Behavior [3-6], such behavior is determined by the attitude towards the behavior that can be enhanced through effective Environmental Education (EE) especially in the teaching and learning processes [7]. Indeed, EE is one of the cultural approaches determining the success of combating environmental problems via causal-chain pathways. Learning outcomes in EE are designed to provide sufficient environmental knowledge, understanding, and skills $[8,9]$ that are expected to initiate and shape environmental awareness and sensitivity, attitude and willingness to participate in environmental action [10].

Studies in EE indicated the major outcome of it is to develop environmentally-literate citizenry or environmental literacy $[11,12]$. A representative definition of Environmental Literacy (EL) comes from reference [13] and [11]. Reference [13] defined EL in line with PISA science literacy by including a set of cognitive, affective and skills altogether with an appropriate behavior in a context of environmental awareness and willingness to deal with ideas, topics, and issues related to the environment. Reference [11] defined EL as it has pertained to the capacity to perceive, interpret the relative health of the environmental systems and take appropriate action to maintain, restore, or improve the health of those systems. Yet, three pillars are easily identified from those two aforementioned definitions namely knowledge, attitude, and behavior or action [14]. Examining knowledge, attitude, and behavior is then very important in the study of the effectiveness of the implementation of environmental education.

The Ministry of Education in collaboration with the Ministry of Environment of Indonesia has created EE initiatives and programs and has been continually introducing this eco program to schools in Indonesia. The green-school program or called "Adiwiyata" was initiated in 2009 and has caused a great increase in the school participation since its inception. Several schools have adopted these initiatives with claims on their effectiveness in improving students' environmental awareness and schools' eco-physical environments $[15,16]$. However, the actual impact of these programs on students' environmental knowledge and literacy is usually not well examined and reported. Hence, this green-school program is not well evaluated and, in the light of this, there is a need of measuring EL towards the students to assess the effectiveness of the performed EE program. This study aimed to assess the EL possessed by the 
students under the green-school program in Indonesia and to determine the possible factors related to their achievement. This study limited its scope in assessing

\section{RESEARCH METHODOLOGY}

This research was about to ascertain the factors affecting the particular levels of environmental knowledge and attitude in a qualitative sense. Hence, a qualitative point of view was referred in this research. In this research, five prominent national green schools of the middle-school level in Sragen Regency, Indonesia $\left(7^{\circ} 15 ; 7^{\circ} 30\right.$ southern latitude and $110^{\circ} 45 ; 111^{\circ} 10$ eastern longitude) were chosen to represent the success green schools in Indonesia. Direct observation using a valid and reliable instrument of the environmental literacy test and a prominent closed-ended questionnaire measuring the level of ecological paradigm, the NEP, were used to gain the data of environmental knowledge and attitude from 1203 participants from February to July 2018. Environmental literacy test used in this research consisted of 20 multiple-choice question items and, was used to examine the degree of environmental knowledge. This instrument was developed based on the important ecological concept according to Lewinsohn [17]. Environmental attitude was measured using NEP formula according to Dunlap [18]. In-depth interview towards five Science teachers was also performed to reveal the data related to the possible factors related to a particular degree of environmental knowledge and attitude of the students. The data of environmental knowledge and attitude and, the data from interview were descriptively displayed using SPSS 17.0. They were qualitatively analyzed using context analysis to ascertain the factors related to the particular degree of environmental knowledge and attitude.

\section{RESULT AND DISCUSSION}

\section{A. Levels of Environmental Knowledge}

The result of environmental-knowledge test showed that the observed environmental knowledge of the students was considered low. The data of the students' environmental-knowledge profiles of all green schools in the study scope are given in Fig. 1 as follows:

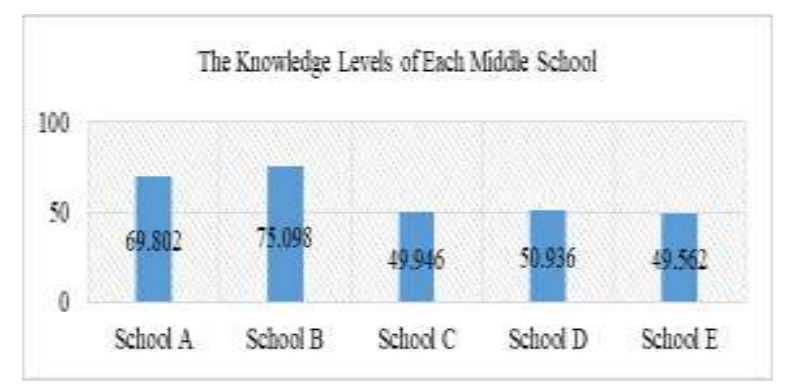

Fig. 1. The Mean Scores of the Environment-Literacy Test of Knowledge Aspect in 5 Green Middle Schools the levels of knowledge and environmental attitudes towards middle-school students in five prominent green schools in Indonesia.

Fig. 1 shows that school B reaches the maximum current criteria-limit of 75 , while the other 4 schools are still under the maximum current criteria. Based on the results obtained from the whole schools, it was found that the overall mean score is 59.068. The low environmental-literacy results can be attributed largely to the learning process in schools that have not maximized the emphasis of environmental literacy. Based on the results of interviews with the Science teachers in the middle schools in Sragen city, there were several problems that may be the cause of the low achievement of the knowledge level of the students' environment. The first, the field of Science of some Science teachers does not come originally from natural science education. Thus, teaching the materials related to Biology especially about their environment, was really constrained in terms of planning, preparing syllabus and lesson plan for teaching materials. This factor is supported by the result of interview with one of the teachers saying, "I am actually a graduate of Physics education. Since the 2013 curriculum applied a year ago in this school, I was required to be able to teach the material about Biology, about the body system and surrounding environment". Secondly, the teachers had time constraints if they had to pack the teaching material into an interesting form of media so that they only rely on the textbooks owned by each student. Third, for the same reason related to the time, the teacher has not maximized the active role of the students in the learning process so that learning still tends to be teacher-centered. The learning models that guide active students such as inquiry-learning model, discovery and problem-based learning have not been applied maximally. This is because the problem emphasis or problem focusing was not done optimally. The students were only guided to basic non-contextual questions. The examples of problems given only from textbooks should be developed by providing an example of more contextual environmental problems with the students' lives. This condition indicated that improvement efforts need to be made to the Science learning process in schools, in terms of the teaching materials used, approaches, strategies, and the models applied.

TABLE 1. The Results of Low-Category Questions Items Related to NEP and Ecological Concepts

\begin{tabular}{cclc}
\hline $\begin{array}{c}\text { Numbers of } \\
\text { Questions }\end{array}$ & $\begin{array}{c}\text { Percent } \\
\text { ages }\end{array}$ & $\begin{array}{c}\text { Question } \\
\text { Points }\end{array}$ & $\begin{array}{c}\text { Cognitive } \\
\text { Levels }\end{array}$ \\
\hline 1 & $0,414 \%$ & $\begin{array}{l}\text { The definition of } \\
\text { ecosystem }\end{array}$ & $\mathrm{C} 4$ \\
\hline 2 & $0.560 \%$ & $\begin{array}{l}\text { The main energy } \\
\text { source (abiotic) }\end{array}$ & $\mathrm{C} 2$ \\
\hline 4 & $0.623 \%$ & $\begin{array}{l}\text { A relationship } \\
\text { among food } \\
\text { webs }\end{array}$ & $\mathrm{C} 3$ \\
\hline 6 & $0.470 \%$ & Phosphorus cycle & $\mathrm{C} 3$ \\
\hline 8 & $0.377 \%$ & $\begin{array}{l}\text { Increased CO } \\
\text { emissions }\end{array}$ & $\mathrm{C} 4$ \\
\hline 9 & $0.417 \%$ & $\begin{array}{l}\text { Providing ideas } \\
\text { or solutions for }\end{array}$ & $\mathrm{C} 6$ \\
\hline
\end{tabular}




\begin{tabular}{|c|c|c|c|}
\hline & & water pollution & \\
\hline 11 & $0.333 \%$ & $\begin{array}{l}\text { Air-pollution } \\
\text { solution }\end{array}$ & C6 \\
\hline 12 & $0.648 \%$ & $\begin{array}{l}\text { Agriculture } \\
\text { against soil } \\
\text { pollution }\end{array}$ & $\mathrm{C} 4$ \\
\hline 13 & $0.376 \%$ & $\begin{array}{l}\text { The } \\
\text { characteristics of } \\
\text { greenhouse gases }\end{array}$ & $\mathrm{C} 1$ \\
\hline 14 & $0.638 \%$ & $\begin{array}{l}\text { The principles of } \\
\text { the greenhouse } \\
\text { effect }\end{array}$ & C3 \\
\hline 16 & $0.638 \%$ & $\begin{array}{l}\text { the impact of } \\
\mathrm{CO}_{2} \text { gas } \\
\text { emissions }\end{array}$ & C5 \\
\hline 17 & $0.417 \%$ & $\begin{array}{l}\text { Giving } \\
\text { conclusions } \\
\text { based on the } \\
\text { tables }\end{array}$ & C5 \\
\hline 18 & $0.533 \%$ & $\begin{array}{l}\text { The function of } \\
\text { the ozone layer }\end{array}$ & $\mathrm{C} 2$ \\
\hline $\begin{array}{c}\text { Noted: Category } \\
\text { High } \\
\text { Medium } \\
\text { Low }\end{array}$ & $\begin{array}{c}\text { umber of } \\
:>0,66 \\
: 0,33 \% \\
:<0,33 \%\end{array}$ & $\begin{array}{l}\text { udents answered co } \\
0.66 \% \text { : }\end{array}$ & \\
\hline
\end{tabular}

Based on TABLE 1, every question can be categorized based on the cognitive level according to Bloom's taxonomy. The percentage of the students who can answer correctly only amounted to $0.333 \%$ of the total number of students is on the question 11 about air-pollution solutions. This problem is at the C6 level because the students were asked to provide solutions in the form of ideas to their surrounding environmental problems. This issue is categorized into NEP aspects of Rejection of the exemptionalism and Limit to Growth. The rejection of the exemptionalism means giving a person a point of view of the rejection of the idea that human is a creature with a responsibility to the environment. Limit to Growth means giving a person's perspective of limits to the growth that have limitations in accommodating human populations and exploitation [19]. Most students cannot correctly answer the cognitive-level categories of $\mathrm{C} 3, \mathrm{C} 4, \mathrm{C} 5$, and $\mathrm{C} 6$ which is also largely categorized as NEP Rejection of the exemptionalism, followed by Limit to Growth and Ecocrisis. This issue was also linked to the ecological concept that should be understood by every individual such as ecosystem resilience, productivity, nutrient cycling, functional redundancy, trophic cascade, habitat fragmentation, community assembly, dispersal, population control, and eco-physiological adaptation [17].

The low percentage of this answer is due to the lack of maximum learning that guides them to actively build their own concepts about contextual environmental issues. Based on the results of interviews and lesson-plan analysis, the examples of environmental problems given were only limited from the existing textbooks. The students were less familiar with the problems close to their daily lives around them so it was difficult for them to analyze and provide the solutions to the environmental problems in the form of ideas. Reference [11] describes the same thing that individuals who have environmental literacy are those who are part of the results of a system that can be broadly grouped into cognitive, affective and behavioral aspects. Improving the skill of environmental literacy is intended to prepare human beings who understand and can solve environmental issues because only environmentalists can find the solutions to the environmental problems.

\section{B. Levels of Environmental Attitude}

The aspects of attitudes include sensitivity to the environment and the motivation to preserve it [20]. Environmental-sensitive attitudes are designed to gain an individual's feelings of pros and cons, favorable or unfavorable, to certain aspects of the environment or objects related to the environment [18], [21], [22]. Dunlap developed the New Ecological Paradigm (NEP) Scale to measure human behavioral readiness for the environment. The NEP scale designed to identify five possible ecological components or socalled dimensions in the NEP [14], [19], [21]. These components include the following Limit to growth, Anti-anthropocentrism, Balance of nature, Rejection of Exemptionalism, and Eco-crisis. The result of the environmental attitude showed that the observed environmental attitude of the students is considered middle-ecological. The data of the students' environmental-knowledge profiles of all green schools in the study scope are given in Fig. 2.

Fig. 2 shows that readiness to behave in an environmentally-friendly manner has shown a positive outcome to the environment. Almost all students as many as $83.52 \%$ have reached the middle category for readiness to behave in an environmentally-friendly manner. The number of students who are antiecological to the environment is $16,48 \%$. The greater percentage of middle-ecological than anti-ecological outcomes implied that students have readiness to behave in a fairly environmentally-friendly manner, although they have not reached the pro-ecological level maximally. The attitudes of the middle-school students seen from the field observation showed that they always kept the cleanliness of their classes and school. In addition, based on the interview with one of the teachers, the school program also has supported the students' readiness to behave by applying the activities that facilitate the students to care about the environment. One of the teachers said, "this school creates a garbage-bank program that trains the students to care for the environment. There is also a clean-Saturday program that trains them to work together to keep the learning environment comfortable".

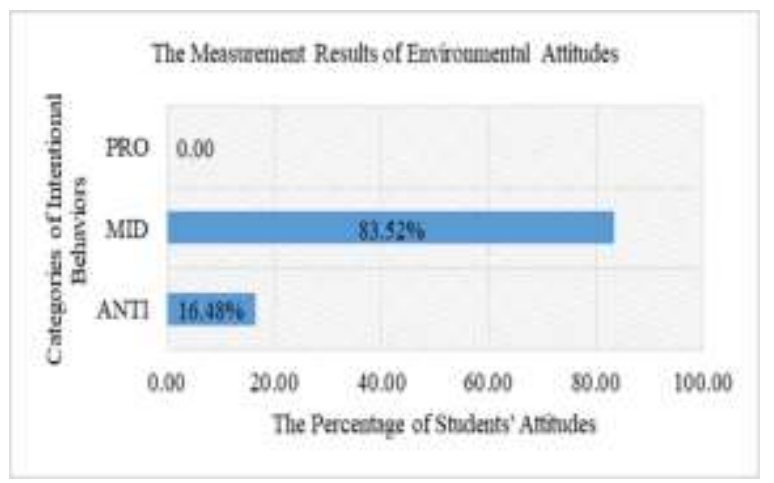

Fig. 2. The Mean Scores of the Environmental-Literacy Test on the Attitude Aspect in 5 Green Middle Schools

On the other hand, it can be seen that the students' readiness to behave environmentally friendly for the 
pro category on the environment is still low or not yet achieved. This can be due to the fact that the input of knowledge coming into the students' thinking about the environment is still in the minimum-average category [24], [25]. It means that the less-maximum knowledge results in the less attitude to the environment as well. Although according to the previous study of Al-dajeh [14], there was no significant relationship between the knowledge and attitude aspects of environmental literacy. Environmental knowledge can affect the students' attitudes and behaviors towards the environment. Based on The Theory of Planned Behavior Ajzen [3] on Figure 3, an environmentally-responsible behavior is initiated by the readiness of individual behavior (intention-behavior). Readiness to behave is followed by contributing variables such as attitudes, social factors, and behavior control. Knowledge becomes the basis for individuals to have the readiness to behave. A lack of environmental knowledge can make people overreact to exploit natural resources that disturbs the natural balance and causes problems. Strengthening environmental literacy is one of the keys to realizing a sustainable environment [26], [27]. Environmental literacy is a knowledge of the environment. Such knowledge can embody individual readiness to take the attitude to decide appropriate actions on the environment.

The NEP-questionnaire items consist of 15 positive and negative statements. Some items about NEP instruments show low scores. Item 5 and 9 are positive statements with the scores of $7.90 \%$ and $7.99 \%$ respectively for the response of strongly agree. Point 5 has a statement of humans are severely abusing the environment. Item 9 states that despite our special abilities, humans are still subject to the laws of nature. Based on items 5 and 9, the students should choose strongly agree with a value greater than $7.9 \%$. Therefore, the intention-behavior to support the environment in both aspects is still low. The NEP scale also has a negative statement for even numbers. Based on Figure 3, it revealed that the students should prefer to choose strongly disagree for the evennumbered items. However, they tend to answer strongly agree and unsure rather than choosing to answer strongly disagree.

The analysis of NEP items showed that the five dimensions of NEP have a mean score under proecological attitudes [20] that are Limit to growth, Anti-anthropocentrism, Fragility of Nature Balance, and Rejection of Exemptionalism, and Possibility of an Eco-crisis as shown in Table 2 as follows.
TABLE 2. The Results of Analysis of Each NEP Item

\begin{tabular}{|c|c|c|c|c|}
\hline No & NEP Indicators & Items & Scores & Mean \\
\hline \multirow[t]{3}{*}{1} & Limit to Growth & NEP 1 & 76,57 & 63,77 \\
\hline & & NEP 6 & 33,56 & \\
\hline & & NEP 11 & 81,19 & \\
\hline \multirow[t]{3}{*}{2} & Anti- & NEP 2 & 37,40 & 53,05 \\
\hline & Anthropocentrism & NEP 7 & 69,96 & \\
\hline & & NEP 12 & 51,78 & \\
\hline \multirow[t]{3}{*}{3} & Fragility of Nature & NEP 3 & 76,07 & 70,05 \\
\hline & Balance & NEP 8 & 59,10 & \\
\hline & & NEP 13 & 74.99 & \\
\hline \multirow[t]{3}{*}{4} & Rejection of & NEP 4 & 48,11 & 52,43 \\
\hline & Exemptionalism & NEP 9 & 63,38 & \\
\hline & & NEP 14 & 45,81 & \\
\hline \multirow[t]{3}{*}{5} & Possibility of an & NEP 5 & 54,92 & 55,04 \\
\hline & Eco-crisis & NEP 10 & 49,72 & \\
\hline & & NEP 15 & 61,55 & \\
\hline
\end{tabular}

Noted: The category of intention-behavior classification based on Waikato Regional \& Technical (2013)

Pro-ecological : :>79

Middle-ecological : 79-54

Anti-ecological : $<54$

According to TABLE 2, it can be said that the aspect number 4 about a rejection of exemptionalism got the lowest mean score that is equal to $52,43 \%$. This aspect explains the indicators indicating that humans must learn from nature to control their natural resources and environment to meet their needs [18], [19], [28]. This low aspect can be attributed to the lack of knowledge of middle-school students around the processing of natural resources for life. Therefore, environmental knowledge must be taught from an early age so that they have enough knowledge to behave environmentally friendly. The most common barriers that prevent pro-ecological behaviors the are lack of knowledge, interests and involvement [24]. Knowledge is very important as a basis for performing an action [25].

Efforts to prevent environmental problems can be done by emphasizing the formation of individual attitudes to behave environmentally friendly. Environmental education is one of the efforts to enter the realm of education. The purpose of environmental education is to realize and shape individuals who have environmental literacy. This environmental-education strategy aims to raise individual awareness of the environment, form the foundation from an early age to contribute to providing environmental solutions and to familiarize themselves with eco-friendly behaviors (Al-dajeh, 2011; Ride et al., 2013). Environmental education can play a role in integrating environmental concepts into school subjects, teaching materials used and extracurricular activities.

\section{CONCLUSION}

The level of environmental literacy in five Green Schools Junior High School in Indonesia is still in enough category because it is only limited to the minimum standard. The learning process that has not yet maximized the indicator of Lewinsohn as an ideal indicator of environmental education and less optimal teaching planning have been two of the causes. 
Environmental knowledge can affect the attitudes and behaviors towards the environment.

\section{ACKNOWLEDGMENT}

The author would like to thank all parties in helping and supporting the completion of this research, especially Mr. Puguh Karyanto, S. Si., M. Si. and Dr. Sarwanto, M. Si who have guided me. In addition, I also thank the Indonesia's Endowment Fund for Education (LPDP) that has given me the opportunity to pursue my master degree.

\section{REFERENCE}

[1] Swim JK, Clayton S, Howard GS. Human Behaviora Contributions to Climate Change: Psychological and Contextual Drivers. Am Psychol. 2011;66(4):251-64.

[2] Vlek C, Steg L. Human Behavior and Environmental Sustainability: Problems, Driving Forces , and Research Topics. 2007;63(1):1-19.

[3] Ajzen I. The Theory of Planned Behavior. 1991;

[4] Lee J, Cerreto FA, Lee J. Theory of Planned Behavior and Teachers' Decisions Regarding Use of Educational Technology. Educ Technol Soc. 2010;13(1):152-64.

[5] Cameron R, Ginsburg H, Westhoff M, Mendez R V. Ajzen's Theory of Planned Behavior and Social Media Use by College Students. Am J Psychol Res. 2012;8(1):1-20.

[6] Hasbullah N, Mahajar AJ, Salleh MI. Extending the theory of planned behavior: Evidence of the Arguments of its Sufficiency. Int J Humanit Soc Sci. 2014;4(14):101-5.

[7] Sarıaya R, Saraç E. An Analysis of Pre - service Teachers 'Attitudes towards Environmental Issues in Terms of Various Variables. Univers J Educ Res [Internet]. 2018;6(1):99-109. Available from: https://www.researchgate.net/profile/Esra_Sarac5/publica tion/321874877_An_Analysis_of_Pre-

service_Teachers\%27_Attitudes_towards_Environmental Issues_in_Terms_of_Various_Variables/links/5a3789ea 0f7e9b10d848b988/An-Analysis-of-Pre-service-

Teachers-Attitudes

[8] Karimzadegan H, Meiboudia H. Exploration of Environmental Literacy in Science Education Curriculum in Primary Schools in Iran. Procedia - Soc Behav Sci [Internet]. 2012 Jan 1 [cited 2018 Feb 5];46:404-9. Available from:

https://www.sciencedirect.com/science/article/pii/S18770 42812012608

[9] Shamuganathan S. Modeling Environmental Literacy of Malaysian Pre- University Students. 2015;10(5):757-71.

[10] Ride BBMCB, Rewer CAB, Erkowitz ARB, Iteracy L, Al MET. Environmental literacy, ecological literacy, ecoliteracy: What do we mean and how did we get here? 2013;4(May).

[11] Roth CE. Document resume ed 348 235. 1990;

[12] Kiarie SM. Effects of Teachers Perceptions On Students , Perceptions and Achievement in Environmental Education in Secondary School Biology in Gilgil Sub- County Nakuru County , Kenya. 2016;11(12):5736-61.

[13] Daniš P. New definition of environmental literacy and proposal for its international assessment in PISA 2015. Envigogika Charles Univ E-Journal Environ Educ [Internet]. 2013;8(3):1-16. Available from: http://www.envigogika.cuni.cz/index.php/Envigogika/art icle/view/385

[14] Al-dajeh HL. Pre-Vocational Education Teachers in Jordan. 2011;492-508.

[15] Siswaningsih W, Sarimaya F. ISBN : 979363174-0 Development dan Pengaruhnya Terhadap Penguasaan Konsep dan Sikap Siswa. 2014;33-43.
[16] Susilastri SD, Rustaman NY. Students , environmental Literacy Profile in School-Based Nature and in School that Implement the Adiwiyata Program. 2015;263-9.

[17] Attayde L, Fonseca CR, Lewinsohn TM, Kollmann J, Overbeck GE, Ganade G, et al. Ecological literacy and beyond : Problem-based learning for future professionals. 2015;154-62.

[18] Dunlap RE, Liere KD Van, Mertig AG, Jones RE. Measuring Endorsement of the New Ecological Paradigm : A Revised NEP Scale. 2000;56(3):425-42.

[19] Erdogan M. The Effect of Summer Environmental Education Program (SEEP) on Elementary School Students ' Environmental Literacy. 2015;10(2):165-81.

[20] Dunlap R. New Ecological Paradigm ( NEP ) Scale. 2012;

[21] Dunlap RE. The New Environmental Paradigm Scale: From Marginality to Worldwide Use. 40(1):3-19.

[22] Kopnina H. No Title. 2011:5(3):374-88.

[23] Regional W, Technical C. New Ecological Paradigm Survey 2008: Analysis of the NEP results. 2013;4355.

[24] Fabrigar LR, Petty RE, Smith SM, Crites SL Understanding knowledge effects on attitude-behavior consistency: The role of relevance, complexity, and amount of knowledge. J Pers Soc Psychol. 2006;90(4):556-77.

[25] Lattner a. D, Gehrke JD, Timm IJ, Herzog O. A knowledge-based approach to behavior decision in intelligent vehicles. IEEE Proceedings Intell Veh Symp 2005 [Internet]. 2005;466-71. Available from: http://ieeexplore.ieee.org/lpdocs/epic03/wrapper.htm?arn umber $=1505147$ 